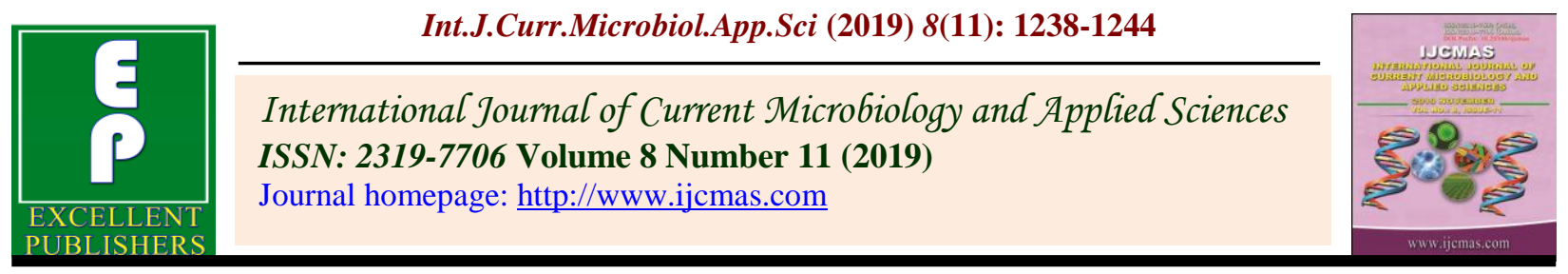

Original Research Article https://doi.org/10.20546/ijcmas.2019.811.145

\title{
Role of VEGF A and FGF 2 in Cell Viability and Apoptosis in Cultured Bubaline Luteal Cells
}

\author{
Meeti Punetha ${ }^{1}$, Avishek Paul ${ }^{1}$, Sai Kumar ${ }^{1}$, Bosco Jose ${ }^{1}$, \\ Jaya Bharati ${ }^{2}$ and Mihir Sarkar ${ }^{1 *}$
}
${ }^{1}$ ICAR-Indian Veterinary Research Institute, Physiology \& Climatology Division, Izatnagar, Bareilly, Uttar Pradesh-243122, India
${ }^{2}$ ICAR-National Research Center on Pig, Rani, Guwahati, Assam 781131, India

*Corresponding author

Keywords

Buffalo, Corpus luteum, VEGF A, FGF 2

Article Info

Accepted:

10 October 2019

Available Online:

10 November 2019

\section{A B S T R A C T}

Pharmacological control of the corpus luteum is significant in the control of the estrous cycle in female buffaloes. The corpus luteum experiences broad cell expansion and separation during luteinization and involutes quickly at luteolysis. Vascular endothelial growth factor (VEGF) and Fibroblast Growth factor (FGF 2) is essential for the angiogenesis required for the formation of the corpus luteum. The aim of this study was to determine the role of VEGF and FGF 2 on cell viability and apoptosis in corpus luteum buffalo. For this purpose, mid stage luteal cell were cultured. The cultured luteal cells were treated with VEGF A $(100 \mathrm{ng} / \mathrm{ml})$ and FGF $2(50 \mathrm{ng} / \mathrm{ml})$ for $72 \mathrm{hrs}$. At the end of the respective incubation periods, viability of cells was done by MTT assay, whereas the cultured cells were used for Caspase 3 mRNA expression by quantitative real-time polymerase chain reaction. The results indicated a significant increase in cell viability in the treatment groups as compared to control. The mRNA expression of Caspase 3 was significantly down regulated in the treatment group in comparison to control groups. Thus, the present finding shows a cell proliferative response of VEGF A and FGF 2 which indicates that these proteins have important role in CL development and function in buffaloes.

\section{Introduction}

The corpus luteum (CL) is an ephemeral endocrine ovarian gland that controls the duration of the estrous cycle and is important for pregnancy establishment and maintenance. In this manner, it is completely necessary to keep up luteal function before fertilization and after implantation. The $\mathrm{CL}$ is among the fastest developing tissues in adult females (Reynolds et al., 1994). This can be further confirmed by the fact that the luteal weight grows by 20 to 30 fold during the first ten days of the estrous cycle (Zheng et al., 1994). 
The CL becomes structurally and functionally mature during the mid-estrous (day 10) and then regresses towards the end of the estrous cycle (Young, 2000). The mature corpus luteum is composed of different types of cells which includes the large luteal cell derived from granulosa cells of ruptured follicle; small luteal cells derived from theca cells of ruptured follicle and the nonsteroidogenic cells which mainly includes endothelial cells and fibroblast cells. During each estrous cycle just after ovulation, luteinization starts which is characterized by the development of CL from the ruptured ovulatory follicle (Senger, 2003). The process of luteinization is mainly dependent upon angiogenesis which involves the development of vascular network and make the CL functional (Tamanini, \&Ambrogi, 2004; Grazul-Bilskaet al., 2001). VEGF and FGF are known for their proangiogenic property in CL.

Vascular endothelial growth factor A (VEGF A) or vascular permeability factor (VPF) and Fibroblast growth factor (FGF 2) is a potent angiogenic growth factor. The physiological effects of VEGF A and FGF 2 are mediated by high affinity tyrosine kinases receptor family. VEGF is regarded as the key endurance factor for endothelial cells (Alon et al., 1995, Benjamin et al., 1999; Gerber et al., 1998a). FGF 1 and FGF 2 applied stimulatory impacts on multiplication of luteal cells and also affects progesterone discharge (GrazulBilskaet al., 1995). As a survival factor, VEGF induces expression of antiapoptotic proteins Bcl-2 and A1 (homolog of the Bcl-2 family) in human endothelial cells (Gerber et al., 1998b). Greenaway et al., (2004) have indicated that VEGF has a cytoprotective role in the bovine extravascular granulosa cell compartment.

Although the role of VEGFA and FGF 2 on cell survivability is distinctly coordinated and well characterized in the bubaline, the molecular mechanism regulating this process in bubaline CL is still not fully understood. Therefore, in the present study, we examined the role of VEGF $A$ and FGF 2 on cell viability and Caspase 3 expression in the cultured bubaline luteal cells.

\section{Materials and Methods}

\section{Luteal cell culture}

Buffalo ovaries were collected from a local abattoir and transported to the laboratory in $\mathrm{PBS}$ at $37^{\circ} \mathrm{C}$ in a vacuum flask. Corpus luteum samples from mid luteal phase (MLP; Days 5$10 ; n=4)$, of the estrous cycle were used for the study, and these were selected on the basis of the criteria outlined previously (Sarkar et al., 2010). The CL at mid luteal stage demonstrated red darker to orange shading, growing vessels showing up at the outskirts and apex with delicate to compact consistency. The CLs were removed from the ovary with all connective tissue, blood clot and then, they were sliced up using BP blades (Bard-Parker Surgical Blade). The minced luteal tissue was washed three times for 5 minutes at $1000 \mathrm{rpm}$ with the culture medium DMEM. All cells (including luteal, endothelial, pericytes, and fibroblasts) were dispersed by incubating the luteal tissue in DMEM medium containing $2 \mathrm{mg} / \mathrm{mL}$ of collagenase 1 type 1A (C-0130; Sigma), $25 \mathrm{mg} / \mathrm{mL}$ of DNase1 (D-5025; Sigma), and 0.5\% BSA (A2058; Sigma) for 45 minutes (two times) shaking in an incubating shaker at $37^{\circ} \mathrm{C}$. The dispersed cells from each incubation were pooled together and then filtered through a 70-mm cell strainer (C93070; SPL Life Sciences) to remove non dissociated tissue fragments. The filtrate was then washed twice by centrifugation for 5 minutes at $1000 \mathrm{rpm}$ with DMEM media. Erythrolysis was accomplished by washing the pellet with RBC lysis buffer. Cell viability was measured using the trypan blue. The cells 
were thereafter plated out at $1.5 \times 10^{5}$ viable cells per well in a 24-well plate (total volume: 1 -mL media containing $12 \%$ fetal bovine serum and antibiotic and antimycotic solution in a humidified $\mathrm{CO} 2(5 \%)$ incubator at $37^{\circ} \mathrm{C}$. The cells were allowed to attach and grow (75\%-80\% confluent) for 48 hours. Then, the medium was replaced with fresh medium containing VEGF A concentrations (100 $\mathrm{ng} / \mathrm{mL})$ and FGF $2(50 \mathrm{ng} / \mathrm{ml})$ and the cells were cultured for 72 hours. Control cells were grown in medium without VEGF A and FGF 2.

MTT \{3-(4,5-dimethylthiazole-2-yl)- 2,5diphenyltertrazoliumbromide\} Assay

The primary culture luteal cells were seeded on 96 well plates and incubated at $37^{\circ} \mathrm{C}$ for 72 hour with media containing $(100 \mathrm{ng} / \mathrm{ml})$ of VEGF A and $(50 \mathrm{ng} / \mathrm{ml})$ of FGF 2. From that point forward, $10 \mu \mathrm{l}$ of $5 \mathrm{mg} / \mathrm{ml}$ of 3-(4,5dimethylthiazole-2-yl)- 2,5-diphenyltertrazolium bromide (MTT; MP Biomedicals) was added to each well and cells were further cultured for 4 hours at $37{ }^{\circ} \mathrm{C}$. At that point, supernatant was removed and $100 \mu \mathrm{l}$ of DMSO (MP Biomedicals) was added and optical density was read at $450 \mathrm{~nm}$ with ELISA reader (Biorad, Microplateperuser).

\section{Primers}

Primers were designed using the Fast PCR (Version 6.2.73) software. Details of the primers are given in Table 1.

\section{Quantitative Real Time PCR analysis}

Total RNA was isolated by Trizolreagent from cultured luteal cells of Mid stages CL $(n=4)$ from all three groups which include control, VEGF A, FGF 2respectively, according to manufacturer instructions. The RNA quality was verified by agarose gel electrophoresis. Constant amounts of 500ng of total RNA were reverse transcribed using Thermo Scientific
Revert Aid First Strand cDNA synthesis kitandoligo-dT18 primer at $42^{\circ} \mathrm{C}$ for $60 \mathrm{~min}$ followed by heating at $70 \mathrm{oC}$ for $5 \mathrm{~min}$. The resulting complimentary DNAs (cDNAs) were used in $\mathrm{qPCR}$ reactions.

The qPCR for each cDNA and the housekeeping gene RPS15A was performed in duplicate using the SsoFast Eva Green Supermix kit (BioRad) in a Biorad CFX manager Real-Time qPCRTM as per manufacturer's instruction. Briefly, PCR templates containing $0.5 \mu \mathrm{l}$ reverse transcribed total RNA was added to $0.25 \mu \mathrm{l}$ forward primer $(0.2 \mathrm{mM}), 0.25 \mu \mathrm{l}$ reverse primer $(0.2 \mathrm{mM})$ and $5 \mu \mathrm{l}$ of SsoFast Eva Green Supermix kit (BioRad) to a final volume of $10 \mu$ land were subjected to general real-time PCR protocol for all investigated factors. The following general real-time PCR protocol was employed for all investigated factors, denaturation for 30 sec at $95^{\circ} \mathrm{C}, 40$ cycles of a three-segmented amplification and quantification program (denaturation for $05 \mathrm{sec}$ at $95^{\circ} \mathrm{C}$, annealing for10sec at the primer specific temperature $60 \mathrm{oC}$ for all the gene-specific primers understudy), a melting step by slow heating from 61 to $95^{\circ} \mathrm{C}$ with a rate of $0.58^{\circ} \mathrm{C} / \mathrm{sec}$ and a final cooling down to $4^{\circ} \mathrm{C}$. After the run ended, cycle threshold $(\mathrm{Ct})$ values and amplification plot for all determined factors were acquired by using the "SYBR green (with dissociation curve)" method of the Biorad CFX manager Real-Time qPCRTM software.

Real-time PCR efficiencies were determined by amplification of a standardized dilution series, and slopes were obtained. The specificity of desired products was documented using analysis of melting temperature, which is product specific, and a high-resolution gel electrophoresis to verify that transcripts were of exact molecular size and further confirmed by sequence analysis. Negative control PCR containing all components except template was included for 
each sample to check out the formation of primer dimer.

\section{Statistical analysis}

All experimental data are shown as Mean \pm SEM. Efficiency-corrected relative quantification of mRNA was obtained by (Pffal, 2001). The statistical significance of difference in mRNA expression of the examined factors and the MTT assay was assessed using the software SPSS. 22by oneway analysis of variance followed by Tukey's honestly signific ant difference (HSD) test and Differences were considered significant at $p<0.05$.

\section{Results and Discussion}

\section{Effect of treatment of VEGF A and FGF 2} on the luteal cell viability

To understand the effect of VEGF A and FGF 2 on luteal cell viability, MTT assay was performed. The MTT study revealed significant difference in viability between untreated luteal cells and luteal cell treated with VEGF and FGF 2 ( $p>0.05$; Fig. 1). However, there was no significant difference between the VEGF $A$ and FGF 2 treated groups.

\section{Effect of treatment of VEGF A and FGF 2 on the luteal cell apoptosis}

Again mRNA expression study of Caspase 3 was done to confirm the effect of VEGF A and FGF 2 in cell apoptosis. The study revealed significant down regulation in Caspase 3 ( $p>0.05$; Fig. 2) expression in VEGF A and FGF 2 treated luteal cells when compared with luteal cells without treatment. These findings indicate that VEGF A and FGF 2 contribute to luteal cell survival and has anti-apoptotic role in in corpus luteum of buffalo.
VEGF act as the key survival factor for endothelial cells (Alon et al., 1995, Benjamin et al., 1999, Gerber et al., 1998a). VEGF seems to act as both endothelial cell survival and vascular permeability factor (Fraser et al., 2005b). As a survival factor, VEGF induces expression of antiapoptotic proteins Bcl-2 and A1 (homolog of the Bcl-2 family) in human endothelial cells (Gerber et al., 1998b). Greenaway et al., (2004) have indicated that VEGF has a cytoprotective role in the bovine extravascular granulosa cell compartment. Coexpression of VEGF and Flk-1/KDR in bovine ovarian granulosa cells protect these cells against apoptotic cell death and follicle atresia. The protective effect of VEGF in the granulosa cells appears to occur via interaction with Flk-1/KDR. VEGF effect on endothelial and granulosa cells suggest that decline of VEGF expression is one of the mechanisms involved in vascular dissolution as well as in functional and structural luteolysis of luteal cells.

FGF 1 and FGF 2 exerted stimulatory effects on proliferation of luteal cells and had variable effects on progesterone secretion (GrazulBilskaet al., 1995). Neutralization of FGF 2 by injecting FGF2 antibody leads to a reduction in luteal growth and steroidogenesis in bovine CL (Yamashita et al., 2008). According to Mishra et al., (2016) PCNA and BAX mRNA expression suggests both proteins role in preventing luteal cell apoptosis and possibly acting as a cytoprotective factor to stimulate luteal cell survival. Thus, the patterns of mRNA expression and MTT assay of VEGF $A$ and FGF 2 treated luteal cells indicates their important role in luteal cell survivability in buffalo CL.

The female reproductive system is an archetype of this principle where various opposing factors are the reason of being for its dynamic nature that causes its ever changing functional status. 
Table.1

\begin{tabular}{|c|c|c|c|}
\hline Gene & Sequence of Nucleotide (5'-3') & $\begin{array}{c}\text { Amplicon } \\
\text { Length (bp) }\end{array}$ & $\begin{array}{c}\text { EMBL accession } \\
\text { no.or reference }\end{array}$ \\
\hline RPS15A & $\begin{array}{c}\text { Forward: AGGGCTGGGAAAATTGTTGTGAA } \\
\text { Reverse: TGAGGGGATGGGAGCAGGTTAT }\end{array}$ & 104 & Paul et al., 2018 \\
\hline Caspase3 & $\begin{array}{c}\text { Forward: CAGGGTGCCCAGGACTTTAG } \\
\text { Reverse: AGAAAGCTCACGGGAACCAG }\end{array}$ & 165 & NM_001077840.1 \\
\hline
\end{tabular}

Fig.1 Demonstration of percentage viable luteal cells treated with VEGF A (100ng/ml) and FGF 2 (50 $\mathrm{ng} / \mathrm{ml}$ ) at $72 \mathrm{hrs}$ at $370 \mathrm{C}$. MTT was added $5 \mathrm{mg} / \mathrm{ml}$ to each well and further incubated for $4 \mathrm{~h}$ and absorbance was measured at $450 \mathrm{~nm}$ using 96-plate reader to measure cell proliferation. Abbreviation: MTT, 3-(4,5-dimethylthiazole-2-y)-2-5-diphenyltetrazolium bromide.

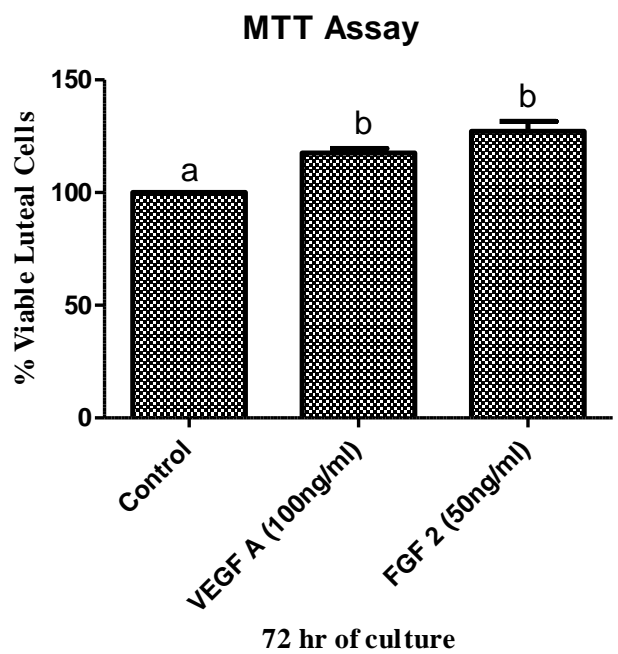

Fig.2 Effect of VEGA and FGF 2 on mRNA expression of Caspase 3 in in vitro luteal cell culture. Briefly, cells isolated from mid stage CL (Days 5-10 )were stimulated with VEGFA (100ng/ml) and FGF $2(50 \mathrm{ng} / \mathrm{ml})$ at $75-80 \%$ confluency over a period of $72 \mathrm{~h}$. Cell lysate was used for the extraction of total RNA and cDNA preparation. Each point in the graph indicates Mean \pm SEM. Different superscripts denote statistical significance $(p<0.05)$

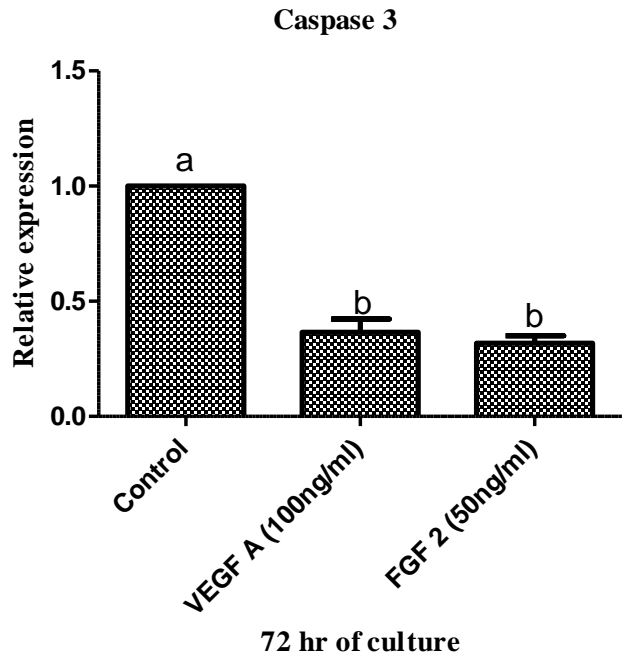


The corpus luteum (CL) is one such tissue that exhibit regular periods of growth (angiogenesis), steroidogenic function and luteolysis (CL regression).

Several locally producing ovarian growth factors seem to play an important role in development and maintenance of corpus luteum of water buffalo.

The present study indicates that VEGF A and FGF 2 are two important growth factors which play a significant role in averting luteal cell apoptosis and also has a cytoprotective role so as to animate luteal cell endurance.

\section{Acknowledgements}

We thank Director of Indian Veterinary Research Institute for providing necessary facilities for conducting this research work.

\section{References}

Alon, T., Hemo, I., Itin, A., Peer, J., Stone, J. and Keshet, E. 1995. Vascular endothelial growth factor acts as a survival factor for newly formed retinal vessels and has implications for retinopathy of prematurity. Nat med 1(10): 1024-1028.

Benjamin, L. E., Golijanin, D., Itin, A., Pode, D. and Keshet, E. 1999. Selective ablation of immature blood vessels in established human tumors follows vascular endothelial growth factor withdrawal. JCI.103(2): 159-165.

Fraser, H. M., Wilson, H., Morris, K. D., Swanston, I. and Wiegand, S. J. 2005 b. Vascular endothelial growth factor Trap suppresses ovarian function at all stages of the luteal phase in the macaque. J Clin Endocrinol Metab. 90(10): 5811-5818.

Gerber, H. P., Dixit, V. and Ferrara, N. 1998a. Vascular endothelial growth factor induces expression of the antiapoptotic proteins $\mathrm{Bcl}-2$ and $\mathrm{A} 1$ in vascular endothelial cells. J. Biol. Chem. 273(21): 13313-13316.

Gerber, H. P., McMurtrey, A., Kowalski, J., Yan, M., Keyt, B. A., Dixit, V. and Ferrara, N. 1998b. Vascular endothelial growth factor regulates endothelial cell survival through the phosphatidylinositol 3'-kinase/Akt signal transduction pathway requirement for Flk-1/KDR activation. J. Biol. Chem.. 273(46): 30336-30343.

Grazul-Bilska, A. T., Redmer, D. A., Jablonka-Shariff, A., Biondini, M. E. and Reynolds, L. P. 1995. Proliferation and progesterone production of ovine luteal cells from several stages of the estrous cycle: effects of fibroblast growth factors and luteinizing hormone. Can. J. Physiol. Pharmacol. 73(4): 491-500.

Grazul-Bilska, A. T., Reynolds, L. P., Bilski, J. J. and Redmer, D. A. 2001.Effects of second messengers on gap junctional intercellular communication of ovine luteal cells throughout the estrous cycle.Biolreprod. 65(3): 777-783.

Greenaway, J., Connor, K., Pedersen, H. G., Coomber, B. L., LaMarre, J. and Petrik, J. 2004. Vascular endothelial growth factor and its receptor, Flk$1 / \mathrm{KDR}$, are cytoprotective in the extravascular compartment of the ovarian follicle. Endocrinology, 145(6): 2896-2905.

Mishra, S.R., Parmar, M.S., Yadav, V.P., Reshma, R., Bharati, J., Bharti, M.K., Paul, A., Chouhan, V.S., Taru Sharma, G., Singh, G. and Sarkar, M. 2016. Expression and localization of angiopoietin family in corpus luteum during different stages of oestrous cycle and modulatory role of angiopoietins on steroidogenesis, angiogenesis and survivability of 
cultured buffalo luteal cells. Reprod Domest Anim. 51(6): 855-869.

Pfaffl, M.W. 2001. A new mathematical model for relative quantification in real time RT-PCR.Nucl.AcidRes.29.

Reynolds, L. P., Grazul-Bilska, A. T., Killilea, S. D. and Redmer, D. A. 1994.Mitogenic factors of corpora lutea. Prog growth factor res. 5(2): 159-175.

Sarkar, M., Schilffarth, S., Schams, D., Meyer, H. H., and Berisha, B. 2010. The expression of leptin and its receptor during different physiological stages in the bovine ovary. MolReprodDev: Incorporating Gamete Research, 77(2): 174-181.

Senger D.R., Van de Water L., Brown L.F., Nagy J.A., Yeo K.T., Yeo T.K., Berse B., Jackman R.W., Dvorak A.M., Dvorak H.F. 1993. Vascular permeability factor (VPF, VEGF) in tumor biology. Cancer and Metastasis Reviews 12: 303-324.

Tamanini, C. and De Ambrogi, M. 2004. Angiogenesis in developing follicle and corpus luteum. Reprod Domest Anim. 39(4): 206-216.

Yamashita, H., Kamada, D., Shirasuna, K., Matsui, M., Shimizu, T., Kida, K., Berisha, B., Schams, D. and Miyamoto, A. 2008.Effect of local neutralization of basic fibroblast growth factor or vascular endothelial growth factor by a specific antibody on the development of the corpus luteum in the cow. Mol Reprod Dev. 75:14491456.

Young F.M., Rodger F.E., Illingworth P.J. and Fraser H.M. 2000.Cell proliferation and vascular morphology in the marmoset corpus luteum. Hum Reprod. 15: 557-566. doi: 10.1093/ humrep/15.3.557. PubMed: 10686196

Zheng J, Fricke PM, Reynolds LP and Redmer DA. 1994. Evaluation of growth, cell proliferation, and cell death in bovine corpora lutea throughout the estrous cycle. Biol Reprod. 51: 623-632. doi:10.1095/biolreprod51.4.623.

PubMed: 7819442

\section{How to cite this article:}

Meeti Punetha, Avishek Paul, Sai Kumar, Bosco Jose, Jaya Bharati and Mihir Sarkar. 2019. Role of VEGF A and FGF 2 in Cell Viability and Apoptosis in Cultured Bubaline Luteal Cells. Int.J.Curr.Microbiol.App.Sci. 8(11): 1238-1244. doi: https://doi.org/10.20546/ijcmas.2019.811.145 